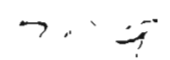

IP for the purpose of obtaining data on mining and prospecting. A falrly complete tebulation of present activities 1s appended. The Individual operations are covered by means of the Placer Mintag Forms, whtch have been formarded to the Territorial Department of Mines at Juneau. As this district has been visited by another associate engineer of the Department of Mnes, and is covered in a general way by a recent IJ.S.G.S. report (BuIl 844-D), this report will confine itself to present mining, prospecting, and related activities.

\section{Prospecting and Mtning}

There has been considerable activity this season, and both production and prospecting should continue to increase for several years. The larger outflts have large reserves of workable ground and are carrying on, or starting, drilling programs on several creeks that have been morked in the past, but which are unproductive at present. Also several individuals and small groups mill prospect this winter, using light 4 and 5 inch drills, on what may be considered in part as new creeks. Others have been prospecting by means of open cuts and shafts. Thil it was impossible to evaluate the individual prospects in the time avallable, the fect remains that a good deal of prospecting is going on, and the outlook for future gold production is good.

In general the creeks mined in this district are shallow, thawed and wet. Deep, frozen minting ground is encountered on Sulliven, Deep and Woodchopper Creeks, on lower Boulder Creek, and eround Molverine Creek on the North Forik of Baker Creek. Because of the wat ground, drills usually are necessary for prospecting.

Hutlinana Creek and its tributaries in the vicinity of Hutlinana Rot Springs have been staked and soveral drilling outflts will prospect there this 
wiater. The reglon between the upper Hutlinana, the Rampart District and the Livengood District, while somewhat difflcult of access at present, is regarded as promising, and doubtless will be given more attention by prospectors in the near future.

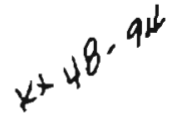

Twenty-five claims on Eureka Creek are under option to the Cleary Hills Mining Co., and were drilled last sumer. The Montana Mining Co. has optioned 18.16 most of the claims on Seattle and Rhode Island Creaks and intends to arill there thls winter. The Montang Minlng Co. started mining on Omega Creak last year w1th 18.16 no preliminary prospecting. As they do not know the exact location or extent of the workable ground, the cuts have not been located to best advantage, and some good ground hag been covered with tallings. Onder the present management a drililing program has been started, and it is anticipated that they soill get stralghtened out.

The high benches on Ploneer Creek, most of which is held by Mrs. Linnie F. t itself Dumeen, appear to have been largely worked out. The creek, has been little worked, and is a possible dragline proposition, although considerable tallings from the bench have been dumped on it.

In the Tofty area there still is some drift mining and prospecting on Sullivan and Deep Creeks. Some of this deep ground may be dredgable. The American Creek dredge 18 again operating, under competent management, and should be more successful than in the past. There are no serious operating difficulties on American Creek, excepting that it has not been possible to thaw ground for dredging during the following summer. The wind keeps the creek swept bare of snow, so that with no insulating coverling the graval freezes back 9 or 10 feet to bedrock during the winter. This fall the maneger intends to trg flooding a thawed area to see if will the 1 ce covering afford sufficient insulation to prevent aeep freezing back. Some difficulty in prospecting accurately with smell drills, especially in wet ground, is anticlpeted. The use of caisgons and portable pumps in shallow, wet 
ground was recomended, either to supplement or to replace the drilling. In some cases small test cuts would be more satisfactory.

Transportation and Communication

The roads in the Eureks and Tofty areas are shown in the sketch maps in U.S.G.S. Bull. 844-D, excepting about seven miles of recently bullt road leading from the mouth of Ploneer Creek to upper Omega Creek. The roads in the Eureke area are fairly good in dry weather and soft in wet weather. The chlef need is for a heavy toppling of gravel. Portions of the rodas have been graveled recently. The available grevel in this area appears to be of poor quality for rosd surfacing and not well distributed.

The road from Bot Springs to Tofty was impassable. In many places deep gulles have been eroded, removing all traces of the road. A small Road Commisalon crew was laying corduroy on parts of the roed between Hot Springs and Blowbeck Creek. This seems to be the only means of building a fairly permanent road over the moss, niggerheads, and generally swempy country that this road must traverse. The soll is easily aroded when the moss covering is stripped, hence it would appear that grading does more harm than good.

The cost of bulling and maintaining satisfactory roads over this type of country appears from casual observation to be disproportionate to the benefits derived. It would seem that the operators could freight in their heavy supplies in the spring, using cats and sleds. Inder normal spring conditions this would be cheaper than freighting by truck over poor roads.

The Hot Springs District is well supplied with sultable landing fields, as shown by the following list: 
$-4-$

Location

Hot Springs

Eureka (Mouth PIoneer Cr.s)

Omega Cr. at Alpha Cr.

Sullivan Cr.

(nr. Softy Gulch)

Head of Deep Cr. (ar. Miller Cr.)

American Cr.
Approx. Size

$1100 \times 300$

$1200 \times 300$

$1200 \times 300$

$1200 \times 300$

$1200 \times 300$

$1500 \times 200$
Remarks

Condition Good

11

" FaIr

" "Sort in wet weather. Built by Clears Hills Min. Co., called leary Hill Fie

Condition Fair. Called Miller Field.

Good; built on tailings by Am. Cr. Min. Co. $4 b^{2}$

Airplane freight and passenger rates from Hot Springs to the various landing fields are relatively low and the service 19 good. It should be feasible to use this service for emergencies and for shipping in perishables, while bulk of the supplies could be brought in by cats and sleds, as previously indicated. Telephone service is available from the landing fields and most of the mines to Hot Springs. The Ines are kept in repair by Mr. Gus Benson, who also is commissioner and recorder for the district.

W. R. foresting, Avert Min. Eng. 